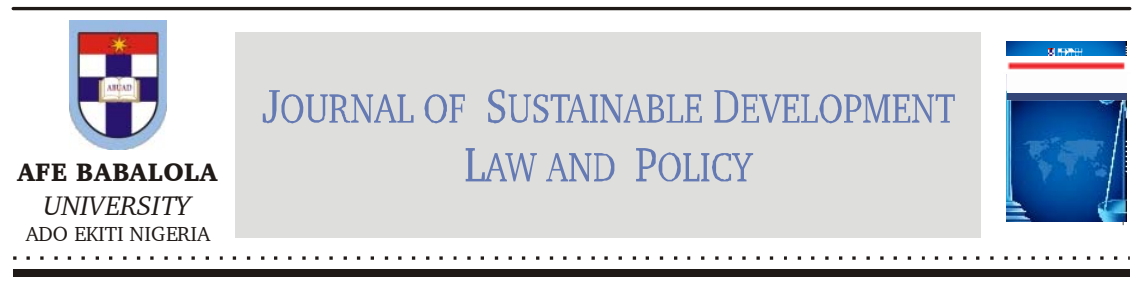

\title{
ATTAINING THE SUSTAINABLE DEVELOPMENT GOALS IN AFRICA: THE NEW CSR FOR MULTINATIONAL CORPORATIONS
}

\author{
Nojeem Amodu*
}

\begin{abstract}
The fact that Africa is one of the worst performing regions in global audits about long-term development trends is longer news. The continent has repeatedly missed targets set by the United Nations and there are concerns it might just be left behind in the attainment of the latest 2030 Agenda Sustainable Development set by world leaders in 2015. With a view to complementing states' responsibilities towards the provision of public goods and social services useful to actualize the Sustainable Development Goals (SDGs) in Africa, this article interrogates the nature of multinational corporations (MNCs) and juxtaposing the non-state actor responsibilities within wider societal contexts with state duties in advancing the SDGs. The article not only sets the tone for a "new corporate social responsibility" in terms of improved pursuit of sustainability within business communities in corporate Africa, it also recommends workable measures, integrating progressive roles for both the state and MNCs towards the realization of the SDGs on the continent.
\end{abstract}

Keywords: Corporate Responsibility; MNCs; SDGs in Africa; New CSR Roles; Regional Integration.

DOI: https://dx.doi.org/10.4314/jsdlp.v11i2.5

* Postdoctoral fellow at the University of Cape Town, South Africa. Email: nojeem.amodu@uct.ac.za 


\section{INTRODUCTION}

Towards addressing the global challenges of poverty, inequality, climate change, environmental degradation, peace and justice, all UN Member States in 2015 adopted the 2030 Agenda for Sustainable Development ${ }^{1}$ setting out yet another ${ }^{2} 15$-year plan to achieve a few developmental goals as now popularly referred to as the Sustainable Development Goals (SDGs). They constitute the blueprint to achieve a better and more sustainable future for all. The SDGs built on the successes of previous developmental agendas, pulling together strands of the 1972 Stockholm Declaration, ${ }^{3}$ the Brundtland Report, the 1992 Rio Declaration ${ }^{4}$ and the Millennium Development Goals (MDGs) ${ }^{5}$ of the year 2000. ${ }^{6}$ The 2030 Agenda for Sustainable Development is a comprehensive, far-reaching and demanding international agreement among world leaders, recognizing the interlocking nature of global challenges with its 17 goals, 169 integrated and indivisible targets, and 230 indicators.

The concept of sustainable development as further elaborated within the framework of the SDGs has snowballed into an idea that dominates the international landscape and is now seen as an ideal to strive for, and

1 United Nations General Assembly Transforming our World: the 2030 Agenda for Sustainable Development resolution adopted by the General Assembly on 25 September 2015, UN Doc A/RES/70/1.

2 This is subsequent to the earlier 15-year plan called the Millennium Development Goals (MDGs) adopted in September 2000 by world leaders at the United Nations Headquarters in New York. General Assembly resolution 55/2 of 08 September 2000.

3 Stockholm Declaration on the Human Environment in Report of the United Nations Conference on the Human Environment, UN Doc A/CONF.48/14, at 2 and Corr.1 (1972).

4 Rio Declaration on Environment and Development, in Report of the United Nations Conference on Environment and Development, UN Doc. A/CONF.151/26 (Vol. I), 12 August 1992, Annex I. The Rio Declarations from the 1992 United Nations Conference on Environment and Development (UNCED), in Rio de Janeiro, Brazil were re-affirmed at the (another Earth Summit, Rio+10) World Summit on Sustainable Development (WSSD) held in Johannesburg, Republic of South Africa in September 2002. In 2012, the United Nations Conference on Sustainable Development (UNCSD), known as Rio +20 was also held in Brazil as a 20-year follow up to UNCED.

5 General Assembly resolution 55/2 of 08 September 2000.

6 Nojeem Amodu "Corporate Social Responsibility and Economic Globalization: Mainstreaming Sustainable Development Goals into the AfCFTA Discourse" (2020) 47:1 Legal Issues of Economic Integration 71-104, 77. 
as the starting point for any meaningful discussions on development. ${ }^{7}$ The business community also caught on to the idea of sustainability ${ }^{8}$ and it is a catch-all term used by multinational corporations or enterprises (MNCs) to encompass a range of actions and activities relating to the environment, profitability and corporate social responsibility (CSR). ${ }^{9}$

However, while the awareness for sustainability has attained universal significance, much of what companies do to achieve sustainable development is still done on a more or less voluntary basis as there are often no mandatory laws (both domestic and international) to be adhered to. ${ }^{10}$ In other words, although almost everyone - including MNCs acknowledges the need to work on the actualization of the SDGs, there is yet to be any concrete, robust and comprehensive enforcement framework towards their realization. ${ }^{11}$ This challenge is exacerbated within the continent of Africa which has not only missed previously set global goals for development but also generally has very weak (if not

7 Yinka Omorogbe "Universal Access to Modern Energy Services: The Centrality of the Law" in Yinka Omorogbe and Ada Okoye Ordor (eds) Ending Africa's Energy Deficit and the Law: Achieving Sustainable Energy for All in Africa (Oxford: Oxford University Press 2018) 7.

8 The terms "sustainability" and "sustainable development" are generally considered synonymous and have been used interchangeably in this article. Nojeem Amodu "Corporate Social Responsibility and Economic Globalization: Mainstreaming Sustainable Development Goals into the AfCFTA Discourse" (2020) 47:1 Legal Issues of Economic Integration 71, 74. However, some writers are of the view that they do not really mean one and the same. Guller Aras and David Crowther "Sustainable Practice: The Real Triple Bottom Line" in Guller Aras and David Crowther (eds.) Development in Corporate Governance and Responsibility - The Governance of Risk (Emerald Group Publishing Limited, 2013) 4 and 5.

9 Andrew Keay and Taskin Iqbal "Sustainability in Large UK Listed Retail Companies: A Sectoral Analysis" (2018) 23 Deakin Law Review 209, 213.

10 See generally, Reinhard Steurer and others "Corporations, Stakeholders and Sustainable Development" (2005) 61 Journal of Business Ethics 263.

11 Enforcement of accuracy of details in sustainability reporting and CSR reports is criticized as being largely reliant on the "naming and shaming" philosophy where identification of disparity between what is disclosed and what is actually practised may lead to being shamed in the public domain and such risk of reputational damage is expected to pressurise companies to behave responsibly and sustainably. See for instance, Douglas Branson "Corporate Governance "Reform" and the New Corporate Social Responsibility" (2001) 62 University of Pittsburgh Law Review 605, 646 giving a few instances of sustainability misrepresentations such as in the 1990 suit by six US states against Mobil Oil for marketing Hefty trash bags as bio-degradable despite knowledge that the bags would not degrade in landfill. 
poorly enforced) or sometimes non-existent regulatory framework for corporate responsibility and accountability. ${ }^{12}$ Further to the recent realization for redistribution of responsibilities between state and nonstate actors to countervail the powerful influence of MNCs, ${ }^{13}$ a pertinent question appears to be, can non-state actors, including MNCs, be assigned new or additional responsibilities beyond their current roles towards supporting governments in the actualization of the SDGs? Is it desirable for states to impose further constraints on MNCs beyond the narrow pursuit of profit towards the attainment of the SDGs in Africa?

This article argues that it is not only desirable but also commercially feasible in the long run for MNCs to play improved roles in the wider societal context. These roles should be supportive of state responsibilities towards the realization of target developmental goals on the African continent. In reaching the conclusion, this article proceeds as follows. Using this introduction as a springboard, section 2 describes the pursuit of sustainable development within business communities in terms of the concept of corporate social responsibility (CSR). Section 3 juxtaposes the respective sustainability roles of MNCs and states, highlighting perceived challenges undermining the attainment of the SDGs in Africa. Section 4 makes a few recommendations, integrating the roles of state and non-state actors with a view to ensuring countries in Africa do not, once again, miss out on global developmental targets. The article concludes in section 5 .

\section{SUSTAINABILITY AND CORPORATE SOCIAL RESPONSIBILITY}

Sustainability has not only been identified as a multi-dimensional concept that is contested, controversial ${ }^{14}$ and difficult to define in any precise fashion, ${ }^{15}$ but perhaps, it is also a concept impossible to define. ${ }^{16}$

12 See generally, Nojeem Amodu "Regulation and Enforcement of Corporate Social Responsibility in Corporate Nigeria" (2017) 61:1 Journal of African Law 105.

13 Wesley Cragg, Denis Arnold and Peter Muchlinski “Guest Editors' Introduction: Human Rights and Business" (2012) 22:1 Business Ethics Quarterly 1-7, 1.

14 Guller Aras and David Crowther "Sustainable Practice: The Real Triple Bottom Line" in Guller Aras and David Crowther (eds.) Development in Corporate Governance and Responsibility - The Governance of Risk (Emerald Group Publishing Limited, 2013) 4 and 5.

15 Keay and Iqbal, note 9 above at 212.

16 Robert Costanza and Bernard C. Patten "Defining and Predicting Sustainability" (1995) 15 Ecological Economics 193, 193. 
Sustainability, at its broadest, appears to mean the effect that something in the present has on the options available in the future. ${ }^{17}$ Despite some fine lines between them, this article employs sustainability interchangeably with the concept of sustainable development. To this end, and despite a few reservations, ${ }^{18}$ the most widespread definition of the phrase "sustainable development" remains as articulated in Our Common Future 19 as the development that meets the needs of the present without compromising the ability of future generations to meet their own needs. The Brundtland Report, as is otherwise also known, clarified that sustainable development embodies the twin concepts of "need" and "limitations"; while need refers to the essential needs of the world's poor, to which overriding priority should be given; the idea of limitations describes the limitations imposed by present technology and social organization on the environment's ability to meet present and future needs. ${ }^{20}$ Underscoring the nature of the interlocking challenges in the world, ranging from energy, environmental and developmental crises, the report proposed legal principles to safeguard our common future hinging on the three pillars of economic growth, environmental protection and social equity.

The concept of sustainability is accommodated within business communities as a CSR agenda. In other words, CSR, among other connotations, is considered as the business pursuit of sustainable development. ${ }^{21}$ As a corporate governance tool which encourages responsible business conducts in all spheres of business operations, CSR has become inextricably linkable to sustainable development for both business and society. ${ }^{22}$ Accordingly, the agenda for CSR and sustainability

17 Guller Aras and David Crowther "Governance and Sustainability: An investigation into the Relationship between Corporate Governance and Corporate Sustainability" (2008) 46 Management Decision 433, 435.

18 Michael McCloskey "The Emperor Has No Clothes: The Conundrum of Sustainable Development" (1999) 9 Duke Environmental Law and Policy Forum 153.

19 Report of the World Commission on Environment and Development (WCED), Our Common Future, from One Earth to One World1987, annexed to UNGA doc A/42/427 (the "Brundtland Report").

20 Omorogbe, note 7 above at 7.

21 Michael Kerr, Richard Janda and Chip Pitts Corporate Social Responsibility- A Legal Analysis (LexisNexis, 2009) 23.

22 Nojeem Amodu "Sustainable Development and Corporate Social Responsibility under the 2018 Petroleum Host and Impacted Communities Development Trust Bill: Is Nigeria Rehashing Past Mistakes?” (2019) 11 African Journal of Legal Studies 319, 323. 
for companies has come to entail discourse pertaining to carbon footprint and its attendant consequences of global warming and climate change; depletion of primary resources on which the business community rely, such as oil, water, trees, sweatshops, child labour and other human rights violations; systemic failures of the free market system and the lax application of systems of governance and regulations among other things. ${ }^{23}$ To this end and against the backdrop of sustainability reporting by businesses, the interconnectedness of sustainable development and CSR has been described in the following words:

It might entail companies embracing cleaner ways of production, increasing the efficiency of resource use, interacting with social actors in order to improve the performance of businesses in addressing social expectations and redesigning company operations or initiating new ones which give an impetus to a culture of innovation and which ameliorate the position of stakeholders. ${ }^{24}$ (citations omitted)

Beyond the foregoing, which establishes the inseparable nexus between sustainable development and CSR in corporate operations, this article also clarifies its conceptualization of the latter as a business model beyond mere corporate tokenism. ${ }^{25}$ CSR has essentially become an idea to awaken sensitivity to a complex and multi-dimensional debate challenging the role of business in contemporary society. ${ }^{26}$ Along with sustainable development, CSR is conceptualized in this article as a regulatory concept about the acceptance or imposition of constraints in the otherwise narrow pursuit of profit goal in the wider public interest. ${ }^{27}$

23 Id

24 Keay and Iqbal, note 9 above at 214; see also page 42 with the "7 Pillars" of Sustainability in the 2018 Sustainability Report of Dangote Cement Plc, available at http://www.dangotecement.com/sustainability/sustainability-report/ accessed 8 July 2020 ..

25 This conception is, therefore, beyond the CSR historical perspectives in the philanthropic activities of wealthy business owners such as John D. Rockefeller, Andrew Carnegie and Henry Ford who gave away millions of dollars for social uses and causes. Nojeem Amodu Corporate Social Responsibility and Law in Africa (London: Routledge 2020) 4 and 5.

26 Jan Jonker "CSR Wonderland: Navigating between Movement, Community, and Organization" (2005) 20 Journal of Corporate Citizenship 19-22, 21.

27 John Parkinson "Corporate Governance and the Regulation of Business Behaviour" in Sorcha Macleod (ed) Global Governance and the Quest for Justice Volume II, Corporate Governance, (Oxford and Portland: Hart Publishing, 2016) 3 and 4. 
It is a regulatory tool used by the state to getting businesses behave responsibly and accountably for the economic, social, and environmental impacts of their operations, and used as a self-regulatory instrument by businesses (especially MNCs) to remain competitive, managing risks associated with balancing their legal, ethical, social, economic and discretionary responsibilities. ${ }^{28}$ The popularity of the ideas of CSR and the global agenda to actualize the SDGs has continued to snowball within business communities. Corporations of different sizes and in different sectors of the economy have embraced these concepts by producing sustainability and CSR reports. In confirmation of this, further recognizing the need for sustainable business, on 19 August $2019,{ }^{29}$ the Business Roundtable - an association of chief executive officers (CEOs) of America's leading companies ${ }^{30}$ - released the Statement on the Purpose of a Corporation noting that:

While each of our individual companies serves its own corporate purpose, we share a fundamental commitment to all of our stakeholders. We commit to: ... supporting the communities in which we work. We respect the people in our communities and protect the environment by embracing sustainable practices across our businesses.... We commit to deliver[ing] value to all of them, for the future success of our companies, our communities and our country. ${ }^{31}$

\section{MULTINATIONAL CORPORATIONS AND STATES' RESPONSIBILITIES FOR ATTAINING THE SDGS}

Understanding the roles played or capable of being played by businesses in the attainment of the SDGs entails the appreciation of the nature and

28 Andreas Georg Scherer and Guido Palazzo “Toward a Political Conception of Corporate Responsibility: Business and Society Seen from a Habermasian Perspective" (2007) 32:4 Academy of Management Review 1096-1120, 1096; see also, pages 11 and 21 of the 2018 Sustainability Report of Royal Dutch Shell Plc, available at https://reports.shell.com/sustainability-report/2018/ accessed 8 July 2020.

29 Additional signatures were added on 6 September 2019.

30 These CEO members lead companies with more than 15 million employees and more than US\$7 trillion in annual revenues. See https://www.business roundtable.org/about-us accessed 24 April 2020.

31 Business Roundtable, Statement on the Purpose of a Corporation (Released Updated signatures 6 September 2019). https://opportunity.businessround table.org/ourcommitment/ accessed 24 April 2020. 
extant responsibilities or influence of companies - especially MNCs - in the society. To begin with, attempting a generally acceptable definition of MNCs may not be particularly useful. The Guidelines for Multinational Enterprises by the Organization for Economic Cooperation and Development ("the OECD Guidelines") - the overarching cooperative agreement among adhering states, setting out principles of globally acceptable behaviour for MNCs in the social and environmental spherefound a precise definition of MNCs difficult and not required for the purposes of the OECD Guidelines. ${ }^{32}$ The guidelines describe MNCs instead as enterprises operating in all sectors of the economy, usually comprising companies or other entities established in more than one country and so linked that they may coordinate their operations in various ways. ${ }^{33} \mathrm{~A}$ further description of what MNCs are could be found in the words of Paddy Ireland noting that:

Today, the economically most powerful firms are multinational enterprises made up of connected companies which are regarded for most legal purposes as separate entities - even if, as is usually the case, the organization as a whole is coordinated by a single management team. The resulting structures are complex, involving subsidiaries, cross-holdings, joint-ventures and the like, but it is usually the same mechanism that is at work: direct or indirect control through shareholding. ${ }^{34}$

Even while a precise definition may not be possible, it is nonetheless useful to clarify what MNCs are not. MNCs do not exist as an entity defined or recognized by law. Describing them in terms of moral deflection devices that are used to provide ethical loopholes, Janet Dine noted that MNCs are corporate groups of enterprises made up of complex structures of individual companies with an enormous variety of interrelationships. ${ }^{35}$

32 OECD, OECD Guidelines for Multinational Enterprises (OECD Publishing, 2011) 17; available at http://dx.doi.org/10.1787/9789264115415-en accessed 24 April 2020.

33 Id.

34 Paddy Ireland "Making Sense of Contemporary Capitalism using Company Law" (2018) 33:3 Australian Journal of Corporate Law 379-401, footnote 75 and surrounding texts.

35 Janet Dine Companies, International Trade and Human Rights (Cambridge: Cambridge University Press, 2005) 43-48. 
MNCs comprise companies with separate legal status different from the other group companies and subject to the rules and regulations of the particular country in which it is based, which means that the legal control of the MNC as a whole and its transnational activities is fragmented among the different states in which business activities are undertaken by its individual group members. ${ }^{36}$

MNCs have essentially become drivers of globalization. The dominance of the shareholder primacy model has facilitated the rise of the shareholder value MNCs around the world which has in turn not only contributed to the global growth in income and wealth inequality but also welded these corporate groups into a new aristocracy of finance. ${ }^{37}$ This has also encouraged what Gerald Epstein referred to as the "financialization" of the global economy. ${ }^{38}$ The significance of the above general description of the role and nature of the MNCs is a confirmation of the immense powers and global influence MNCs have come to assert. MNCs are so powerful that they do not only influence national laws but also impact the extent of their regulation in international law. An instance could be cited of an Australian based corporation, BHP which had such a strong influence over the government of Papua New Guinea that the government passed laws - understood to have been largely drafted by

36 Liesbeth Enneking Foreign Direct Liability and Beyond Exploring the Role of Tort Law in Promoting Corporate Social Responsibility and Accountability (The Hague: Eleven International Publishing 2012) 16; also Dine, note 32 above at 45; and Jennifer Zerk Multinationals and Corporate Social Responsibility (Cambridge: Cambridge University Press, 2006) 53 noting that business control mechanisms adopted by MNCs in modern times transcends, equity participation or even creating subsidiaries.

37 Paddy Ireland "The Corporation and the New Aristocracy of Finance" in JeanPhilippe Robe, Antoine Lyon-Caen and Stephane Vernac (eds.) Multinationals and the Constitutionalization of the World Power System (Abingdon: Routledge, 2016) 53.

38 Gerald Epstein (ed), Financialization and the World Economy (Edward Elgar 2005) 3; Peter Muchlinski "The Changing Face of Transnational Business Governance: Private Corporate Law Liability and Accountability of Transnational Groups in a Post-Financial Crisis World" (2011) 18 Indiana Journal of Global Legal Studies 665, 678. On page 670, Muchlinski described the term "financialization" as the rise of financial markets over traditional bank lending as the main source of investment capital; the seeking of profits through financial transactions as opposed to more traditional forms of manufacturing, services, or primary goods industries; as well as the changes in corporate governance theory that place enhanced shareholder value at its heart. 
BHP itself - to protect BHP from legal challenge over its activities there, even though those activities had a profound negative impact on its own citizens. ${ }^{39}$

The above highlighted enormous powers and influence coupled with the complex nature of MNCs have made their regulation and the monitoring of the accuracy of disclosures in their sustainability or CSR reports difficult. As a result of this lax regulatory framework examples abound of MNCs either directly violating or caught complicit in abusing their powers and violating human rights together with other adverse impacts in the society. Instances include: (i) the 1984 Bhopal disaster in which a poisonous gas cloud leaked from a pesticide plant in Bhopal, India (owned by an Indian subsidiary of US-based Union Carbide Corporation, now part of Dow Chemical), killing tens of thousands of people living in its vicinity; (ii) Clothing and shoe manufacturers such as Nike which permit extremely poor labour conditions in the factories ("sweatshops") of their overseas suppliers; (iii) the alleged involvement of US oil company Unocal in human rights violations perpetrated by the Burmese military government during the construction of a local gas pipeline; (iv) the 2006 dumping of hazardous waste in Abidjan, Ivory Coast, by a local disposal company entrusted with the waste by petroleum trading multinational, Trafigura; and finally but not the least, (v) the deleterious impacts of over 20 years of oil exploration activities in the Ogoniland region of the Nigerian Niger Delta. ${ }^{40}$

However, the story of the role of MNCs in the society cannot be all gloomy. As Lawrence Mitchell had noted:

No institution other than the state so dominates our public discourse and our private lives.... Corporations make [al]most everything we consume. Their advertising and products fill almost every waking moment of our lives. They give us jobs, and sometimes a sense of identity. They define communities and enhance both our popular and serious culture. They present the investment opportunities that send our children to college, and provide for our old age. They fund our research... The very power that corporations have over our

39 Robert McCorquodale "Corporate Social Responsibility and International Human Rights Law” (2009) 87 Journal of Business Ethics 385, 387.

40 Enneking, note 36 above at 20 to 22 . 
lives means that, intentionally or not, they profoundly affect our lives. ${ }^{41}$

The above will appear to not only underscore the important role MNCs have played but also can play in the pursuit or realization of the SDGs in the mostly under-developed countries of Africa and beyond. Notwithstanding, the increase in the powers of the MNCs as a result of the globalized and financialized world economies also confirms that for MNCs to put their enormous powers and influence to better use in the actualization of the SDGs, improved legal, regulatory and enforcement framework will have to be designed by host states for business operations. Such improved legal and enforcement system is suggested among other recommendations in section 4. Before such recommendations, however, it is useful to clarify the limits of the roles and responsibilities of state actors to ensure that even if MNCs must support the attainment of sustainability goals using their global influence, they should nonetheless not be assigned new or additional responsibilities tantamount to altogether taking over the primary responsibilities of states in providing public goods and social services.

Research has shown that the global rise in the powers of businesses is contrasted with the dwindling powers of state actors, including in Africa. ${ }^{42}$ Notwithstanding this MNC influence and regardless of the dwindling state powers coupled with undermined state sovereignties, MNCs' primary focus should remain largely commercial as the constitutional, fundamental and internationally recognized obligations for the provision of public goods and social services as envisaged within the SDGs remains the primary responsibility of states. The doctrine of state responsibility is embodied within customary international law, ${ }^{43}$ and is reinforced by the doctrine of state duty to protect ${ }^{44}$ human rights under international law. ${ }^{45}$ In further reiteration of the above, it has become

41 Lawrence E. Mitchell Progressive Corporate Law Lawrence E. Mitchell (ed) (Boulder, Colorado: Westview Press 1995) xiii.

42 McCorquodale, note 39 above at 387.

43 Mavrommatis Palestine Concessions Case (1924) PCIJ Series B, No. 3; see also Case Concerning Payment of Various Serbian Loans Issues in France (Series A, Nos 20/21, 29) PCIJ Series A No. 21, 17; and, UN Doc. A/CN.4/SER.A/1956/ Add.1.

44 Art 2(2) and (3) International Covenant on Civil and Political Rights (ICCPR), adopted 16 December 1966, entered into force 23 March 1976, 999 UNTS 171.

45 UN Docs A/HRC/4/35, and A/HRC/4/35/Add.1; Danwood Chirwa "State Responsibility for Human Rights" in MA Baderin and M Ssenyonjo (eds) 
generally accepted that governments, which are accountable to their electorate, should decide matters of public policy, while managers, who are accountable to their shareholders, should run their business and businesses should not try to do the work of governments. ${ }^{46}$ The above proposition informed world leaders' affirmation in the UN 2030 Agenda that:

We reaffirm the importance of the Universal Declaration of Human Rights, as well as other international instruments relating to human rights and international law. We emphasize the responsibilities of all States, in conformity with the Charter of the United Nations, to respect, protect and promote human rights and fundamental freedoms for all, without distinction of any kind as to race, colour, sex, language, religion, political or other opinion, national or social origin, property, birth, disability or other status. ${ }^{47}$

Furthermore, it remains the constitutional responsibility of all organs of the government and of all her authorities and persons, exercising legislative, executive or judicial powers to inter alia, provide equal and adequate educational opportunities at all levels for all and protect and improve the environment and safeguard the water, air and land, forest and wild life of Nigeria among other targets of the SDGs. ${ }^{48}$ Even though such constitutional provisions may be criticized as within the segment ${ }^{49}$ of the constitution considered not justiciable, ${ }^{50}$ the Nigerian state, for

International Human Rights Law: Six Decades After the UDHR and Beyond (Ashgate, 2010) 407.

46 Clive Crook "The Good Company: A Survey of Corporate Social Responsibility" The Economist (22 January 2005) 14, 16.

47 United Nations General Assembly Transforming Our World: the 2030 Agenda for Sustainable Development Resolution adopted by the General Assembly on 25 September 2015, UN Doc A/RES/70/1, para 19.

48 In the case of the Nigerian state, see for instance Chapter II of the Constitution of the Federal Republic of Nigeria, Cap C23 Laws of the Federation of Nigeria 2004.

49 Section 6(6) (c) of the Constitution of the Federal Republic of Nigeria, Cap C23 Laws of the Federation of Nigeria 2004.

50 A right is justiciable if it is "capable of being formulated to impose strict, judicially enforceable obligations" under law. Wade Cole "Strong Walk and Cheap Talk: The Effect of the International Covenant of Economic, Social, and Cultural Rights on Policies and Practices" (2013) 92:1 Social Forces 165-194, 168. 
instance, like all other states in Africa, was also part of the other UN Members who unanimously adopted the 2030 Agenda for Sustainable Development reiterating their commitment to attaining the SDGs. By the adoption of the 2030 Agenda, all states pledged to those universal commitments to strengthen and revitalize the global partnership towards ending poverty, improving health and education, and reducing inequality. Furthermore, as part of the International Bill of Human Rights, ${ }^{51}$ the International Covenant on Economic, Social and Cultural Rights ${ }^{52}$ (ICESCR) - to which Nigeria, together with many other African states, is a member and having ratified it as of 29 July 1993 - is a fundamental pillar of the 2030 Agenda. The common objective between the SDGs and the ICESCR lies in the coordinated efforts to lift everyone out of poverty and ensure that no one is left behind. ${ }^{53}$ In relation to what the role of states are, article 2(1) of the ICESCR is unmissable, ${ }^{54}$ stating that states

51 The International Bill of Human Rights consists of the 1948 Universal Declaration of Human Rights (UDHR) and the main instruments through which it has been codified viz: the International Covenant on Civil and Political Rights (ICCPR); and International Covenant on Economic, Social and Cultural Rights (ICESCR) - coupled with the principles concerning fundamental rights in the eight International Labour Organization (ILO) core conventions as set out in the Declaration on Fundamental Principles and Rights at Work. See generally, United Nations General Assembly, Universal Declaration of Human Rights (UDHR), adopted 10 December 1948, GA Res 217 A (III), UN GAOR, 3rd Session, UN Doc A/810 (1948); the International Covenant on Civil and Political Rights (ICCPR) 1976, opened for signature 10 years before on 16 December 1966, 999 UNTS 171 and entered into force 23 March 1976; and the International Covenant on Economic, Social and Cultural Rights (ICESCR) 1976, opened for signature 10 years on 16 December 1966, 999 UNTS 3 and entered into force 3 January 1976.

52 International Covenant on Economic, Social and Cultural Rights (ICESCR) 1976, opened for signature 10 years on 16 December 1966, 999 UNTS 3 and entered into force 3 January 1976.

53 See paras 4 and 5 of the UN Committee on Economic Social and Cultural Rights Statement, "The pledge to leave no one behind: the International Covenant on Economic, Social and Cultural Rights and the 2030 Agenda for Sustainable Development" E/C.12/2019/ adopted by the Committee at its sixtyfifth session, held from 18 February to 8 March 2019, available at https:// sustainabledevelopment.un.org/content/documents/21780E_C.12_2019_1_ edited.pdf accessed 24 April 2020.

54 See the Maastricht Guidelines on Violations of Economic, Social and Cultural Rights (26 Jan. 1997) para 2 contained in CESCR, Substantive Issues Arising in the Implementation of the International Covenant on Economic, Social and Cultural Rights, UN Doc E/C.12/2000/13 at 16 (2 Oct. 2000) available at https:// www.refworld.org/docid/48abd5730.html accessed 24 April 2020. 
shall undertake steps, individually and through international assistance and cooperation, especially economic and technical, to the maximum of its available resources, with a view to achieving progressively the full realization of the rights recognized in the covenant by all appropriate means, including particularly the adoption of legislative measures. The UN Committee on Economic, Social and Cultural Rights (CESCR) has not only noted the obligation on states to discharge their duty in the ICESCR but also underscored that states will strengthen their ability to realize the SDGs if they do so through sustainable methods ensuring that human rights are secured both for present and future generations. ${ }^{55}$ Perhaps, the most useful international document, though not legally binding, reiterating the state duty and responsibility is the Guiding Principles on Business and Human Rights: Implementing the United Nations' Protect, Respect and Remedy Framework ${ }^{56}$ (UNGPs). While the UNGPs assign the responsibility of respecting human rights to businesses (MNCs inclusive), the core obligation, duty, and responsibility to sustainably protect rights was assigned to states within Pillar I of the framework. ${ }^{57}$ The UNGPs have become useful to highlight in this article since notwithstanding its non-committal, voluntarist approach, ${ }^{58}$ the UNGPs have become a globally indispensable template in any discussions relating to human rights abuses involving businesses using the corporate

55 Note 53 above at para 12 (e) and 18.

56 John Ruggie "Report of the Special Representative of the Secretary General on the issue of human rights and transnational corporations and other business enterprises, Guiding Principles on Business and Human Rights: Implementing the United Nations' Protect, Respect and Remedy Framework” A/HRC/17/31, 21 March 2011 ("UNGPs").

57 The UNGPs rests three pillars: Pillar I - the State duty to protect against human rights abuses; Pillar II - Business must respect human rights ensuring no violation in the course of their operations; Pillar III - As part of their duty to protect, States must take appropriate steps to ensure that when human rights abuses occur within their territory and/or jurisdiction, victims must have access to effective remedy. The principles embedded within the three differentiated pillars ensure the pillars form a complementary whole in that each supports the others in achieving sustainable progress and development. John Ruggie "Protect, Respect, and Remedy: the UN Framework for Business and Human Rights" in MA Baderin and M Ssenyonjo (eds) International Human Rights Law: Six Decades After the UDHR and Beyond (Ashgate, 2010) 528, 520.

58 Nicola Jagers "Access to Justice for Victims of Corporate-Related Human Rights Abuse: An Echternach-Procession" (2015) 3 (33) Netherlands Quarterly of Human Rights 269-273, 269 and 270. 
form. ${ }^{59}$ In light of the foregoing clear demonstration of the state responsibility to ensure the SDGs and targets are met, the article submits that governments, including those in Africa, cannot afford to abdicate their responsibilities to MNCs notwithstanding the enormous power, influence and control of the business community. If states in Africa must scale up on their sovereign responsibilities and will not abandon their responsibilities towards the actualization of the SDGs in the face of the snowballing powers of MNCs, what measures may they take using the CSR framework towards assigning additional but sustainable responsibilities to MNCs such that the SDGs can be attained? Workable measures to help in this regard are recommended in section 4.

\section{SPECIFIC STATE MEASURES TOWARDS REALIZING THE SDGS}

Two major points are gleaned from the foregoing discussions. One is that MNCs have so much grown in powers and influence in our highly globalized and financialized societies that intentionally or not, they affect virtually everything in the human society and a re-assignment of new roles (as additional corporate social responsibilities) on them is desirable, if not long overdue. The second major point is that regardless of the fact that state powers might have waned so much that MNCs dictate policy directions to them, states and governments cannot afford to abandon their constitutionally recognized and international-law-reinforced duties of ensuring the fulfilment of citizens' civil, political, economic, social and cultural rights embedded within the SDGs. If no one will be truly left behind in poverty and the excesses of MNCs must be curbed, including rampant deprivation of citizens' socio-economic, cultural and other rights, states cannot simply afford to leave the shareholder-primacy-modelstrengthened MNCs to their whims and caprices in their otherwise narrow pursuit of profit. Fostering of partnership between state and non-state actors have become more imperative than ever. The following recommendations, therefore, appear pertinent:

\subsection{New CSR Roles for African States}

African states must see the twin concepts of sustainable development

59 Juan Pablo Bohoslavsky, Liber Martín and Juan Justo “The State Duty to Protect from Business-related Human Rights Violations in Water and Sanitation Services: Regulatory and BITs Implications" (2015) 26 International Law 63,116. 
and corporate social responsibility as described in section 2 for what they are. Sustainability is not just about MNCs dishing out CSR or sustainability reports without anyone testing, monitoring, or confirming the accuracies of information disclosed and reported. CSR, it must never be forgotten, transcends corporate charity, mere tokenism, or undertaking community development projects like providing pipe-borne water, hospitals, schools or giving scholarships out of excess corporate profits. CSR originated in corporate governance reforms as a countervailing power employed by the government to check the raw exercise of corporate powers in the interest of the public. CSR is, therefore, a veritable regulatory instrument in the hands of an enlightened government - with keen determination to discharge its constitutionally-entrenched duty as recognized in international law - to safeguard the rights of all individuals within its jurisdiction, be it civil rights, political rights, economic rights, social rights or cultural rights. All African states must see the pursuit of CSR activities towards the actualization of the SDGs within the business community as an instrument of getting MNCs to respect and cause no harm within wider societal contexts. Relevant amendments to the corporate law systems in respective jurisdictions which otherwise encourages a CSR implementation as an idea of simply giving back to the society by MNCs should be revisited if no one is to be left behind. Provisions in many African states' corporate law system with which the identified shareholder primacy model has been entrenched should be amended to tilt towards corporate stakeholder with more friendly provisions. ${ }^{60}$ Awakening from any slumber of corporate influence and bondage, African governments need to countervail the enormous powers and influence of MNCs and adopt policies taking CSR and the realization of the SDGs as a continuous process of safeguarding the interests and rights of all corporate stakeholders in the society, including the host communities, the employees, the customers and consumers, creditors, government agencies and so on.

\subsection{New CSR Roles for the MNCs}

MNCs also need to improve on their CSR conceptualization and their business pursuit of sustainability. Businesses do not exist in isolation in the society. MNCs must realize that but for the wide recognition, constant interaction and concession of the state and society - society comprising

60 Amodu, note 25 above at chapter 2. 
of other constituents of the company, including the creditors, the employees, the customers, the host and impacted communities, and the natural environment - businesses cannot survive, operate, function or otherwise achieve any economic gains, growth or development. ${ }^{61} \mathrm{MNCs}$ must, therefore, see the need to strategically employ CSR, beyond corporate philanthropy, as a corporate governance tool to manage the social, economic and environmental risks associated with their operations. Adopting effective internal CSR policies, MNCs will be able to carry out efficient and continuous due diligence exercises with which they can identify and review any negative impacts of business operations on corporate stakeholder rights and assess possible measures for the prevention or mitigation of such. ${ }^{62}$ The scope of due diligence may vary from business to business, transaction to transaction and depending on circumstances. This way, MNCs will be putting their enormous powers, influence and control in the society to good and effective use. They will, accordingly, be taking steps and undertaking activities supportive of the government towards the realization of the SDGs rather than causing harm and jeopardizing such realization. To be clear, engaging in such due diligence is not corporate waste but an effective strategy of not only maintaining the MNCs social license to operate ${ }^{63}$ within the communities but also sustainably complementing the state duty and responsibility to achieving the SDGs. This recommendation and its adoption are also compliant with the UNGPs framework as the leading globally acceptable template for redistribution of responsibilities between the state and businesses.

\subsection{Integrated Regional Response in Africa}

As it was long established from the Brundtland Report, the framework of the present UN 2030 Agenda for Sustainable Development recognizes that many of the world's challenges are interlocked and cross-border.

61 Ibid at 60.

62 Johanna Fournier and Lukas Heckendorn Urscheler "International Standards in the Domain of Corporate Social Responsibility" in Lukas Heckendorn Urscheler and Johanna Fournier (eds) Regulating Human Rights Due Diligence for Corporations (Geneva/Zurich: Swiss Institute of Comparative Law 2017) 21.

63 Jason Prno "An Analysis of Factors Leading to the Establishment of a Social Licence to Operate in the Mining Industry" (2013) 38 Resources Policy, 577-590. 
Furthermore, regardless of the CSR policies and continuous due diligence exercises by MNCs, infringement of rights, especially those cutting across borders because of the complex set up of the MNCs, will very likely continue. Therefore, the steps taken by African states at their respective domestic levels towards improving corporate responsibility of MNCs will have certain limitations. First, where the domestic CSR policies in one state are considered too stringent, MNCs are well financed and financialized to decide moving to jurisdictions with weaker regulatory framework. Second, such domestic steps taken by states may not address corporate irresponsibility of MNCs which are cross-border in nature. Although it is recognized that no law restricts states from taking steps with exterritorial application to address such cross-border abuses by MNCs, such steps run the risk ${ }^{64}$ of inter-state friction. In light of the foregoing challenges, the framework of the "Agenda 2063" adopted by African leaders at the AU Summit in 2015 - calling for a prosperous Africa based on inclusive growth and sustainable development and expressing vision that Africa shall be a continent where the free movement of people, capital, goods and services will result in significant increases in trade and investments among African countries - therefore comes in very handy. The African Continental Free Trade Area (AfCFTA) ${ }^{65}$ is the flagship project of Agenda 2063 of the AU with which African states intend to achieve the SDGs. The recommendation is that because of the cross-border nature of the activities and likely abuses caused by MNCs, African governments need to properly mainstream CSR implementation within the framework of the AfCFTA such that the exercise of raw corporate powers by the powerful MNCs may be better checked at the intergovernmental level of the AU. The ambit of this proposed

64 Ole Kristian Fauchald and Jo Stigen "Corporate Responsibility Before International Institutions" (2009) 40 The Geo. Wash. Int'l L. Rev. 1027, 1028.

65 See the Agreement Establishing the African Continental Free Trade Area and its Protocols, Annexes and Appendicesat:https://au.int/en/treaties/agreementestablishing-african-continental-free-trade-area accessed 24 April 2020. AfCFTA covers the entire 55-member states of Africa with a market of 1.2 billion people and a gross domestic product of $\$ 2.5$ trillion and as a result of the share number of participating countries, AfCFTA constitutes the world's largest free trade area since the formation of the World Trade Organization. See, African Trade Policy Centre United Nations Economic Commission for Africa, "African Continental Free Trade Area - Questions \& Answers" available at https:// www.uneca.org/publications/african-continental-free-trade-area-questionsanswers accessed 24 April 2020. 
recommendation has been argued elsewhere. ${ }^{66}$ It suffices, therefore, to summarize that this proposal calls on states in Africa to mainstream effective CSR conceptualization and implementation framework within the regional integration discourse in Africa. This will see the adoption of a CSR implementation protocol to the AfCFTA agreement together with regular releases of directives for legal transposition within respective domestic corporate law systems across African countries. This provides a shared CSR policy framework in Africa and harmonizes the overall sustainable development agenda across the continent towards the attainment of the SDGs. The proposed framework will also address instances of jurisdictional arbitrage or MNCS forum shopping from one jurisdiction in Africa to another as may otherwise be believed with too stringent regulations. This recommendation also offer support in addressing the challenge of double standards of some MNCs with different CSR policy standards from one jurisdiction to the other. Adopting the foregoing strategies, the article submits that African states will better discharge their responsibilities, ensuring not only effective lifting of their citizens out of poverty and other social challenges but also giving themselves the chance of not being left behind in yet another global developmental target by 2030 .

\section{CONCLUSION}

This article observed that with a view to addressing the global challenges of poverty, inequality, climate change, environmental degradation, world leaders in 2015 adopted the 2030 Agenda for Sustainable Development, setting out yet another 15-year plan to achieving the developmental goals popularly referred to as the Sustainable Development Goals. The SDGs were said to have built on previous developmental agendas such as the 1972 Stockholm Declaration, the 1987 Brundtland Report, the 1992 Rio Declaration, and the year 2000 MDGs. This article argued that Africa is missing out on previous global developmental goals. For Africa to stand a better chance of not being left behind again in the 2030 global developmental target and advancing towards the framework of the "Agenda 2063" adopted by African leaders calling for a prosperous Africa based on inclusive growth and sustainable development, this article underscored the need for effective pursuit of sustainable development in

66 Amodu, note 25 above at 208. 
terms of CSR activities of businesses, especially by MNCs. Having juxtaposed MNC and state responsibilities in advancing sustainable development, the article identified challenges jeopardizing the realization of the SDGs in Africa. Among other factors, the article emphasized the dwindling economic resources at the disposal of many states together with waning states' power to achieving the SDGs. This was contrasted with the enormous powers of highly financialized, shareholder-primacymodel-strengthened MNCs which can be leveraged to either jeopardize or complement state responsibilities in the course of advancing sustainability. As fostering of partnership between state and the nonstate actors had become imperative, the article concluded on a note of recommending additional but integrated responsibilities for both states and MNCs giving the African continent a chance of performing better in the global audits about the 2030 long-term developmental agenda. 